\title{
Neuronal nicotinic acetylcholine receptors serve as sensitive targets that mediate $\beta$-amyloid neurotoxicity ${ }^{1}$
}

\author{
Qiang LIU, Jie WU ${ }^{2}$ \\ Division of Neurology, Barrow Neurological Institute, St Joseph's Hospital and Medical Center, Phoenix, Arizona 85013, USA
}

\author{
Key words \\ nicotinic acetylcholine receptor; $\beta$-amyloid \\ peptides; neurodegeneration; Alzheimer's \\ disease \\ ${ }^{1}$ Part of the work performed in Dr WU's \\ laboratory was supported by an Arizona \\ Alzheimer's Disease Core Center (ADCC) \\ Pilot Research Grant. \\ ${ }^{2}$ Correspondence to Dr Jie WU. \\ Phn 1-602-406-6376. \\ Fax 1-602-406-7172. \\ E-mail Jie.Wu@chw.edu \\ Received 2006-06-14 \\ Accepted 2006-07-03 \\ doi: $10.1111 / \mathrm{j} .1745-7254.2006 .00430 . \mathrm{x}$
}

\begin{abstract}
Alzheimer's disease (AD) is the most common form of brain dementia characterized by the accumulation of $\beta$-amyloid peptides $(A \beta)$ and loss of forebrain cholinergic neurons. $A \beta$ accumulation and aggregation are thought to contribute to cholinergic neuronal degeneration, in turn causing learning and memory deficits, but the specific targets that mediate $\mathrm{A} \beta$ neurotoxicity remain elusive. Recently, accumulating lines of evidence have demonstrated that $A \beta$ directly modulates the function of neuronal nicotinic acetylcholine receptors (nAChRs), which leads to the new hypothesis that neuronal nAChRs may serve as important targets that mediate $A \beta$ neurotoxicity. In this review, we summarize current studies performed in our laboratory and in others to address the question of how $\mathrm{A} \beta$ modulates neuronal nAChRs, especially $\mathrm{nAChR}$ subunit function.
\end{abstract}

\section{Introduction}

Alzheimer's disease (AD) is a syndrome of dementia, characterized by gradual degeneration of basal forebrain cholinergic neurons innervating the cortex, amygdala and hippocampus, which manifests itself through difficulties in maintaining and sustaining attention, and profound cognitive impairments, such as loss of memory and the ability to learn ${ }^{[1-4]}$. These deficits are thought to be due to selective forebrain cholinergic neuronal degeneration ${ }^{[5]}$. Thus far, the mechanisms of selective cholinergic neuronal degeneration have been hypothesized to include the impairment of neuronal trophic support, disorders in glucose metabolism or other processes ${ }^{[6]}$, but the precise mechanisms involved are still largely unclear. Recently, accumulating lines of evidence have shown that there is a crucial impairment of nicotinic acetylcholine receptor (nAChR) binding sites in the brain of $A D$ patients ${ }^{[7,8]}$. $\beta$-amyloid peptides $(A \beta)$ directly modulate $n A C h R$ function ${ }^{[9-13]}$. Nicotinic agents have been found to improve cognitive function in $\mathrm{AD}$ animal models and $A D$ patients ${ }^{[14-17]}$, suggesting that a relationship exists between $n A C h R s$ and $A \beta$. Therefore, the neuronal $n A C h R$ is likely to play an important role in mediating both $\mathrm{A} \beta$ toxic- ity and neural degeneration, and may serve as a therapeutic target for the treatment of AD.

\section{Neuronal nAChRs}

\section{Structure and distribution of nAChRs in the central nervous system (CNS)}

nAChRs are prototypical members of the ligand-gated ion channel superfamily of neurotransmitter receptors. nAChRs represent both classic and contemporary models for the establishment of concepts pertaining to mechanisms of drug action, synaptic transmission and structural/functional diversity of transmembrane signaling molecules ${ }^{[18-24]}$. $\mathrm{nAChRs}$ are found throughout the nervous system (eg in autonomic and sensory ganglia and the CNS), exist as multiple, diverse subtypes, and are pentamers composed of unique combinations from a family of at least $17(\alpha 1-\alpha 10$, $\beta 1-\beta 4, \gamma, \delta$ and $\varepsilon$ ) similar, but genetically-distinct, subunits. Each subunit gene has a unique promoter, even though some genes are clustered, suggesting a means for cell-specific expression. There are also unique protein sequence elements within each subunit, especially in the large, cytoplasmic loop, suggesting a differential post-translational control of sub- 
unit trafficking. Most of these nAChR subtypes appear to exist as heteropentamers containing 2 or more different kinds of subunits. For example, heterologous expression studies suggest that $\alpha 2, \alpha 3, \alpha 4$ or $\alpha 6$ subunits can combine in a binary fashion with $\beta 2$ or $\beta 4$ subunits to form ligand-binding and/or functional nAChRs (eg $\alpha 4 \beta 2-n A C h R s) . ~ \beta 3$ and $\alpha 5$ subunits are 'wild-cards'. They are not able to form functional nAChRs on their own or with any other single type of subunit, but they are capable of integrating into complexes with 2 or more other subunit types to form distinctive trinary or ternary (that also contain more than one of the $\alpha 2-\alpha 4, \alpha 6$, $\beta 2$ or $\beta 4$ subunits found in binary complexes) complexes such as the $\alpha 4 \beta 2 \alpha 5-\mathrm{nAChR}$ or the $\alpha 3 \beta 2 \beta 4 \alpha 5-\mathrm{nAChR}$ (which is naturally expressed). In contrast, phylogenetically-ancient nAChR $\alpha 7$ subunits are able to form functional homopentamers, which constitute the simplest possible prototype for a ligand-gated ion channel. $\mathrm{nAChRs}$ containing $\alpha 7 \mathrm{sub}$ units $(\alpha 7-\mathrm{nAChR})$ or $\alpha 4$ and $\beta 2$ subunits $(\alpha 4 \beta 2 *$-nAChR) are the most abundant curaremimetic neurotoxin-binding and high affinity nicotine-binding $\mathrm{nAChR}$ in the brain. However, other less-abundant nAChRs (eg $\alpha 3{ }^{*}$-nAChR or $\alpha 6^{*}$ $\mathrm{nAChR}$ ) exist and may also play important roles in brain physiological regulation.

\section{Function of neuronal nAChRs}

$\mathrm{nAChR}$ function in vertebrate muscle has been comprehensively characterized, and studies of functional nAChRs in autonomic ganglia are rather advanced ${ }^{[23,24]}$. In regards to nAChRs found centrally, there has been heavy reliance on heterologous expression studies, principally using oocytes as hosts, but the use of transfected mammalian cells has also assisted in defining the realm of possibilities for $\mathrm{nAChR}$ subunit compositions that are capable of forming functional, ligand-gated ion channels. Significant insights have been gained about functional nAChRs in the brain from a substantial body of evidence derived using electrophysiological recordings, neurotransmitter release analyses, isotopic ion flux studies and internal calcium ion imaging. Studies using transgenic mice have helped to identify subunits that constitute some native, functional nAChR subtypes ${ }^{[25-30]}$. Taken collectively, recent findings have indicated that $\mathrm{nAChRs}$ in the brain play roles not only in the mediation of classic, excitatory, cholinergic neurotransmission at selected loci, but also and perhaps more globally, in the modulation of neurotransmission of other chemical messengers, including glutamate, $\gamma$-aminobutyric acid (GABA), the monoamines dopamine (DA), norepinephrine, serotonin and ACh itself ${ }^{[23,31-33]}$. This means that some $\mathrm{nAChR}$ subtypes have post-synaptic (or peri-synaptic) somatodendritic locali- zations, whereas others have pre-synaptic dispositions. Moreover, some nAChRs have been implicated in processes such as the structuring and maintenance of neurites and synapses ${ }^{[34-36]}$ and even in the modulation of neuronal viability and/or death ${ }^{[37-40]}$. Therefore, nAChRs play complex and interesting roles in the modulation of chemical milieu in the brain, for the completion of neuronal circuits, and perhaps for the formation and maintenance of synapses. However, more work is required to define functional nAChRs in the CNS and to determine their cellular distributions. Additional studies are also required to determine whether distinctive subunit combinations dictate whether a given nAChR subtype will be positioned pre- or post-synaptically or whether the same nAChR subtype can have either disposition depending on the cellular environment.

As examples, functional nAChRs in the hippocampus, in neurons of the mesocorticolimbic DA system, including the ventral tegmental area (VTA) and substantia nigra pars compacta (SNc), or in forebrain cholinergic neurons, have received attention $^{[41-46]}$. Some of these functional analyses utilized electrophysiological recordings from brain slices as well as primary cultured hippocampal neurons. Recent exceptions include studies demonstrating the expression in the VTA of functionally distinct nAChRs, including homomeric $\alpha 7$ nAChRs, which are expressed on less than one-half of VTA DAergic neurons, and a variety of non- $\alpha 7-n A C h R s$, provisionally identified as $\alpha 4 \alpha 6 \alpha 5(\beta 2)_{2^{-}}, \alpha 4 \alpha 5(\beta 2)_{2^{-}}, \alpha 6 \beta 2-$, and $\alpha 4 \beta 2-\mathrm{nAChRs}{ }^{[26,47,48]}$. One complication is that the function of some of these putative subtypes has not been convincingly demonstrated, leaving open the possibility that the immunoisolates are not functional $\mathrm{nAChRs}$ found on the cell membrane. Interestingly, GABAergic neurons located in the VTA are likely to express relatively simple nAChR subtypes, mainly the $\alpha 4 \beta 2-\mathrm{nAChR}$, since less than $25 \%$ of GABAergic neurons express $\alpha 3, \alpha 5, \alpha 6$ and $\beta 4$ subunits $^{[26]}$. Recently, several research groups have focused their attention on $\mathrm{nAChR}$ function in forebrain neurons ${ }^{[49-51]}$ and have found that these nAChRs not only participate in forebrain neuronal function, but are also modulated by $A \beta^{[52]}$. The diversity in the expression of nAChR subtypes and subunits on different types of neurons located in different brain regions might be the rule more than the exception for other brain regions, but more work is needed before definitive conclusions can be drawn.

\section{Neuronal nAChR changes in AD}

The roles of nAChRs in cognitive function and development are well documented ${ }^{[53,54]}$. Impaired cognition found in $\mathrm{AD}$ patients is believed to be correlated with forebrain cho- 
linergic neural degeneration ${ }^{[55,56]}$, and the cholinergic system has been postulated to be the primary target in $\mathrm{AD}^{[57,58]}$. Molecular and neurochemical evidence have indicated that changes in $\mathrm{nAChR}$ subtypes occur in the brain of $\mathrm{AD}$ patients. Evidence also indicates that a consistent, significant loss of $\alpha 4$-containing nAChRs occurs in a number of neocortical areas and in the hippocampus of patients with $\mathrm{AD}^{[59,60]}$. Cortical $\alpha 4^{*}$-nAChR deficits are significantly correlated with cognitive impairment in AD patients ${ }^{[61,62]}$. For example, by measuring the binding of specific radiolabeled ligands, such as $\left[{ }^{3} \mathrm{H}\right]$ epibatidine and $\left[{ }^{125} \mathrm{I}\right] \alpha$-bungarotoxin to reflect receptor numbers, a reduction in $\alpha 4$ - and $\alpha 7-\mathrm{nAChR}$ binding sites was found to be associated with $\mathrm{AD}$. On the other hand, the numbers of binding sites reflective of the $\alpha 4$ subtype were significantly elevated in individuals who were habitual smok$\mathrm{ers}^{[63-65]}$. However, mRNA levels of different nAChR subtypes, measured either by in situ hybridization or quantitative RT-PCR, were not different when controls and patients with $\mathrm{AD}$ were compared ${ }^{[66,67]}$. At the protein level, $\alpha 3$ and $\alpha 4$ subunit expression in the temporal cortex and hippocampus, and $\alpha 7$ subunit expression in the hippocampus, were significantly lower in AD patients compared to controls ${ }^{[66,68]}$. Immunohistochemical analyses have shown a significant reduction in the $\alpha 4$ subunit, but not the $\alpha 7$ or $\alpha 3$ subunits, in the brain of $\mathrm{AD}$ patients following autopsy compared to agematched samples ${ }^{[63,69,70]}$. In summary, the above data suggest that there is a reduction in the number of $\mathrm{AChR}$ binding sites in the brain of patients with $\mathrm{AD}$ at the protein level, but not the mRNA level, which implies that the reduction is likely to be due to $\mathrm{AChR}$ post-translational malfunction.

\section{$A \beta$ peptides and neurotoxicity $A \beta$ and senile plaques}

Plaques are defining neuropathological hallmarks of AD and $\mathrm{A} \beta$, the major constituent of plaques, is considered to play an important role in the pathophysiology of AD. Clinical evidence indicates that amyloid plaques are responsible for the pathogenesis of $\mathrm{AD}^{[5]}$. These plaques are mainly composed of the $A \beta$ peptide, which is obtained from an amyloid precursor protein (APP) by proteolytic cleavage and exists in 2 predominant forms: the 40-residue $\mathrm{A} \beta_{1-40}$ and the $42-$ residue $A \beta_{1-42}$. $A \beta_{1-40}$ represents the majority of the $A \beta$ population in normal individuals $\mathrm{s}^{[25]}$ and $A \beta_{1-42}$, which exhibits trophic and toxic effects on neurons ${ }^{[5,71]}$, appears to induce the pathogenesis of AD.

\section{$A \beta$ accumulation in $A D$ : in vivo and in vitro studies}

A large body of evidence indicates that the accumulation of large intracellular and extracellular aggregates is a histopathological hallmark for the terminal diagnosis of AD. However, it has long been known that the extent of amyloid accumulation does not correlate well with $\mathrm{AD}$ pathogenesis ${ }^{\text {[72] }}$ and that a significant number of individuals who have not suffered dementia have also shown notable amounts of amyloid plaques. Among in vivo transgenic animals and in vitro cell culture models, pathological changes are frequently observed prior to the onset of amyloid accumulation. These seemingly conflicting lines of evidence can be reconciled by postulating that soluble $\mathrm{A} \beta$, rather than the mature fibrils, represents the primary toxic species in amyloid-associated degenerative disease ${ }^{[73,74]}$. In $\mathrm{AD}$ patients, soluble $\mathrm{A} \beta$ correlates better with cognitive decline and loss of synaptic proteins than insoluble, fibril deposits ${ }^{[75,76]}$. In APP transgenic mouse models, neurological deficits precede the deposition of significant amounts of $A \beta$, suggesting that the pathophysiology of $\mathrm{AD}$ occurs prior to amyloid fibril deposition ${ }^{[77,78]}$.

On the other hand, evidence has also shown heterogeneity in extracellular amyloid in plaques ${ }^{[79]}$. Contrary to the popularized dogma that all amyloid plaques arise from extracellular deposition, the different forms and magnitudes of amyloid plaques could be the result of multiple mechanisms of formation. For example, it has been proposed that diffuse and dense-core (senile) amyloid plaques differ with respect to glial activity, with the latter primarily being associated with highly reactive microglia ${ }^{[80]}$. The popular story of extracellular amyloid aggregation which fails to account for the observed heterogeneity in plaques and detected intracellu$\operatorname{lar} \mathrm{A} \beta$ together attract more attention to the mechanisms and intracellular aspects of $A \beta$ plaque formation.

\section{$A \beta$ is neurotoxic}

The addition of $\mathrm{A} \beta$ to cell cultures causes a rapid and large increase in intracellular $\mathrm{Ca}^{2+}$, whereas equivalent amounts of soluble monomer and fibrils have no detectable effects $^{[29,30]}$. Moreover, A $\beta$ specifically permeabilizes cell membranes. The $\mathrm{Ca}^{2+}$ influx is not blocked by cobalt, indicating that the effect is not due to the activation of existing $\mathrm{Ca}^{2+}$ channels. A $\beta$ also causes leakage of the membrane impermeant dye calcein from cells, indicating that a variety of molecules diffuse across the membrane following $A \beta$ treatment. This conclusion is in agreement with previous studies that reported that $A \beta$ induced the release of dye from phospholipid vesicles ${ }^{[81,82]}$. It has also been observed in cell cultures that $A \beta$ treatment results in an increase in cytosolic $\mathrm{Ca}^{2+}$ in $\mathrm{Ca}^{2+}$-free medium. This increase can be 
largely eliminated by pre-treatment with thapsigargin, which depletes endoplasmic reticulum calcium stores ${ }^{[83]}$, suggesting that external application of $A \beta$ leads to the liberation of $\mathrm{Ca}^{2+}$ from intracellular stores. This is consistent with reports that $\mathrm{A} \beta$ may penetrate into cells and disrupt intracellular membranes, causing leakage of sequestered $\mathrm{Ca}^{2+}$, but it could also be the consequence of altered intracellular signaling ${ }^{[84]}$. Under in vivo conditions, the chronic leakage of ions across the plasma membrane may be sufficient to disrupt normal neuronal function and serve as a source of chronic stress that may impair the maintenance of normal membrane potential.

In addition to $\mathrm{Ca}^{2+}$ channel activity, $\mathrm{A} \beta$ also seems to activate $\mathrm{K}^{+}$channels. The mechanism by which $\mathrm{A} \beta$ increases $\mathrm{K}^{+}$current, which results in ensuing neurotoxicity, is unknown, but oxidative stress may be a factor ${ }^{[85,86]}$.

In summary, studies using both in vivo and in vitro preparations indicate that $A \beta$ is neurotoxic and plays a direct role in the pathogenesis of $\mathrm{AD}$.

\section{$A \beta$ modulates $n A C h R s$ Conflicting results}

Recent evidence has indicated that $\mathrm{nAChRs}$ serve as central targets for $A \beta$-induced neurotoxic manifestations such as cholinergic hypofunction and cognitive impairment. However, the action of $\mathrm{A} \beta$ on $\mathrm{nAChRs}$ is not straightforward and there are several discrepancies among different research groups. Some experiments using in vitro preparations suggest that $\mathrm{A} \beta$ acts as a $\mathrm{n} A \mathrm{ChR}$ agonist. For example, $\mathrm{A} \beta_{1-42}$ has been shown to activate $\alpha 7-n A C h R s$ expressed in Xenopus oocytes ${ }^{[11]}$ and native non- $\alpha 7-n A C h R s$ in acutely dissociated rat basal forebrain neurons ${ }^{[52]}$. Using isolated pre-synaptic nerve endings from rat hippocampus and neocortex combined with confocal $\mathrm{Ca}^{2+}$ imaging, $\mathrm{A} \beta_{1-42}$ was found to directly evoke a sustained increase in pre-synaptic $\mathrm{Ca}^{2+}$ levels via $\mathrm{nAChRs}{ }^{[87]}$. This action seemed to involve both $\alpha 7$ - and non- $\alpha 7-n A C h R s$. On the other hand, other groups, including our laboratory, have shown evidence that $\mathrm{A} \beta$ acts on $\mathrm{nAChRs}$ as an antagonist. $\mathrm{A} \beta_{1-42}$ was shown to block native $\alpha 7$-containing $\mathrm{nAChRs}$ in cultured rat hippocampal neurons ${ }^{[10]}$, human $\alpha 7-n A C h R s$ in Xenopus oocytes ${ }^{[88]}$, rat $\alpha 4 \beta 2-n A C h R s$ in Xenopus oocytes ${ }^{[89]}$, human $\alpha 4 \beta 2$ nAChRs in human SH-EP1 cells ${ }^{[90]}$, mouse muscle nAChRs in human kidney BOSC 23 cells $^{[88]}$, Torpedo nAChRs in $\mathrm{Xe}$ nopus oocytes ${ }^{[89]}$ and non- $\alpha 7-n A C h R s$, including $\alpha 2 \beta 2$-, $\alpha 4 \beta 2$ - and $\alpha 4 \alpha 5 \beta 2-n A C h R s$ in Xenopus oocytes ${ }^{[12]}$. Recently, a specific model of interaction between $A \beta$ and $n A C h R s$ was postulated ${ }^{[31,32]}$. In addition, a specially designed peptide that binds to $\mathrm{A} \beta$ with high affinity has been reported, and interestingly, this peptide virtually abolishes
$\mathrm{A} \beta$-induced $\mathrm{nAChR}$ inhibition ${ }^{[91]}$. Therefore, although there are some inconsistencies about the effects of $A \beta$, which may be explained by the different preparations of $A \beta$ used on different subtypes of $n A C h R s$ by different groups, all of the above-mentioned studies prove that $\mathrm{A} \beta$ interacts with nAChRs.

\section{$A \beta$ modulates nAChRs: possible mechanisms}

There are 2 main features of $\mathrm{AD}$ : $\mathrm{A} \beta$ protein deposition and severe cholinergic neuronal deficits. $A \beta$ is a 39- to 43amino acid transmembrane fragment of a large precursor molecule and is found in diffuse and focal deposits throughout the brain in $\mathrm{AD}$ patients. It has been shown that the $\mathrm{A} \beta$ protein is a major constituent of senile plaque, a neuropathological hallmark of $\mathrm{AD}$ and a neurotoxin in various in vivo and in vitro studies. Although the mechanisms by which $\mathrm{A} \beta$ causes cholinergic neuronal degeneration are not fully understood, a few hypotheses have been proposed based on current, growing evidence: (1) neuronal death, either by apoptosis or necrosis, primarily occurs in the cholinergic system; (2) insertion of $\mathrm{A} \beta$ proteins into the cell membrane destabilizes the membrane and affects its fluidity ${ }^{[92-94]}$; (3) $\mathrm{A} \beta$ affects intracellular $\mathrm{Ca}^{2+}$ homeostasis through either the production of cation ionophores or activation of ligand- and/ or voltage-gated channels ${ }^{[95,96]}$, and (4) A $\beta$ affects $n A C h R$ function probably through oxidative processes ${ }^{[97,98]}$. Until now, the precise mechanisms by which $A \beta$ selectively induces degeneration of forebrain cholinergic neurons in $\mathrm{AD}$ patients have been unclear.

\section{$A \beta$ modulates nAChRs: homomeric $\alpha 7-n A C h R s$}

Among nAChRs, the $\alpha 7$ subtype may play the most important role in mediating the toxicity of $\mathrm{A} \beta$. $\mathrm{A} \beta_{1-42}$ binds to $\alpha 7-n A C h R s$ with a higher affinity compared to $A \beta_{1-40}{ }^{[99]}$. Therefore, it has been suggested that chronic stimulation of $\alpha 7-\mathrm{nAChRs}$ by $\mathrm{A} \beta$, mainly by $\mathrm{A} \beta_{1-42}{ }^{[11]}$, elevates, at least in part, intracellular $\mathrm{Ca}^{2+}$ levels. It is also involved in the chronic activation of the extracellular signal-regulated kinase $\left(\mathrm{ERK}_{2}\right)$ isoform of the ERK mitogen-activated protein kinase (MAPK) cascade which leads to the downregulation of MAPK ${ }^{[100]}$. The $\mathrm{ERK}_{2}$-MAPK signaling pathway plays a critical role in memory formation ${ }^{[2]}$, and its derangement could in part explain the memory impairment observed in patients with $\mathrm{AD}$. Moreover, it has been proposed that downregulation of $\mathrm{ERK}_{2}$-MAPK may be the initial step of a positive-feedback loop that results in $A \beta$ accumulation ${ }^{[100,101]}$. There is also another explanation implicating the $\alpha 7-\mathrm{nAChR}^{[102]}$. Using in vitro preparations, the binding interaction between $\mathrm{A} \beta_{1-42}$, 
but not $A \beta_{1-40}$, and $\alpha 7-n A C h R s$ facilitates internalization and intracellular accumulation of $A \beta_{1-42}{ }^{[102]}$. Immunohistochemistry and digital imaging studies have revealed that neurons in the brain of $\mathrm{AD}$ patients which contain substantial intracellular accumulation of $A \beta_{1-42}$ invariably express relatively high levels of $\alpha 7-n A C h R s^{[102,103]}$. Furthermore, these studies prove the high co-localization of $\alpha 7-n A C h R s$ and $A \beta_{1-42}$ within neurons of AD brains. Michael et al introduced a new hypothesis referring to the co-localization of $\alpha 7-n A C h R s$ and $A \beta_{1-42}$. They suggested that amyloid plaques may derive from the lysis of forebrain neurons that are overburdened with intracellular accumulation of the $\alpha 7-\mathrm{nAChR} / \mathrm{A} \beta_{1-42}$ complex, which challenged the prevailing amyloid accumulation story ${ }^{[102,103]}$. This provides a reasonable explanation for $\mathrm{A} \beta_{1-42}$ causing a reduction in the cell surface-associated $\alpha 7-n A C h R$ by a relocation of this receptor to intracellular $\mathrm{A} \beta_{1-42}$-positive deposits. This reduction results in the intracellular derangement of calcium cascade, which in turn leads to selective degeneration of cholinergic and cholinoceptive neurons in $\mathrm{AD}$ brains.

Another consequence of the interaction between $A \beta$ and $\alpha 7-n A C h R s$ would be a derangement of the GABA system, which plays a role in long-term potentiation and learning ${ }^{[104]}$. $\alpha 7$-nAChRs, located on GABAergic interneurons, modulate GABA release, and chronic stimulation of $\alpha 7-n A C h R s$ would modify GABAergic signaling. Taking these results into consideration, compounds that are able to block the effects of $A \beta$ on $\alpha 7-n A C h R$ function may possibly be used as therapeutic agents for $\mathrm{AD}$. Moreover, the mechanisms of $\mathrm{A} \beta$ induced damage implicating $\mathrm{nAChRs}$ have also been proposed to be involved in the glutamatergic system ${ }^{[104]}$. By inhibiting glutamate re-uptake by astrocytes, $\mathrm{A} \beta$ would promote excessive glutamate stimulation. Glutamate induces an increase in intracellular $\mathrm{Ca}^{2+}$ levels via activation of $N$-methyl- $D$-aspartate (NMDA) receptors. This influx of $\mathrm{Ca}^{2+}$ activates nitric oxide (NO) synthase and leads to the production of toxic oxygen radicals and cell death ${ }^{[34]}$. It has also been reported that $\alpha 7-n A C h R$ stimulation would promote antiapoptotic protein synthesis via elevation of intracellular $\mathrm{Ca}^{2+}$ levels and activation of phosphatidylinositol 3-kinase and Akt kinase ${ }^{[105]}$. These results suggest that $\alpha 7-n A C h R$ stimulation could be used as a neuroprotective therapy, which could provide the most benefit to patients with $\mathrm{AD}$ if the disease is diagnosed in the early stages of development. The above-mentioned different mechanisms suggest that the consequences of $\alpha 7-\mathrm{nAChR}$ activation, desensitization or inactivation by $\mathrm{A} \beta_{1-42}$ or $\mathrm{nAChR}$ agonists, such as nicotine, on $\mathrm{AD}$ development are complex or even exhibit opposite effects, suggesting that $A \beta$ modulation of $n A C h R$ function is indeed complicated.

\section{A $\beta$ modulates nAChRs: non- $\alpha 7-n A C h R s$}

A significant decrease in the number of radioligand binding sites corresponding to nAChRs, especially $\alpha 4$-containing nAChRs, is one of the earliest events in the pathogenesis of $\mathrm{AD}^{[106]}$, even preceding cholinergic neuronal degeneration. Further support for the cholinergic hypothesis of $\mathrm{AD}$ comes from observations that nicotine improves cognitive function in $\mathrm{AD}$ patients ${ }^{[107]}$. Accumulating data also indicates that $A \beta_{1-42}$ can block non- $\alpha 7-n A C h R s$ in various neurons or cell lines ${ }^{[92,93]}$.

It has been reported that $\mathrm{A} \beta$ can directly modulate $\alpha 4 \beta 2$ nAChR function ${ }^{[92,93]}$, which is the most abundant non-7nAChR subtype in the brain of vertebrates ${ }^{[60,108,109]}$. Our data have shown that $A \beta_{1-42}$, at a pathology-relevant concentration ( $1 \mathrm{nmol} / \mathrm{L}$ ), can inhibit the human $\alpha 4 \beta 2-\mathrm{nAChR}$ (h $\alpha 4 \beta 2-$ $\mathrm{nAChR}$ ) heterologously expressed in human SH-EP1 cells. $\mathrm{A} \beta_{1-42}$-mediated inhibition of h $\alpha 4 \beta 2-\mathrm{nAChR}$ function is noncompetitive, voltage-independent and use-independent. This downregulation of h $\alpha 4 \beta 2-n A C h R$ function by $A \beta_{1-42}$ has been confirmed to not be mediated by nAChR internalization ${ }^{[90]}$. In addition, we have demonstrated that there is no competition between $\mathrm{A} \beta_{1-42}$, at picomolar to micromolar concentrations, and $\mathrm{nAChR}$ agonists based on radioligand binding sites using heterologously expressed h $\alpha 4 \beta 2-$ or h $\alpha 7-n A C h R s$. Therefore, our findings indicate that $\mathrm{A} \beta_{1-42}$ likely acts as a non-competitive antagonist of ho4 $\beta 2-\mathrm{nAChRs}^{[90]}$.

In Xenopus oocytes expressing various non- $\alpha 7-n A C h R s$, including $\alpha 4 \beta 2$-nAChRs, $A \beta_{1-42}$ can reversibly block membrane currents induced by carbachol. More interestingly, altering the $\alpha 4: \beta 2$ RNA ratio of $\alpha 4 \beta 2$-nAChRs alters the sensitivity of $n A C h R s$ to $A \beta_{1-42}$. In other words, increasing the relative amount of the $\alpha 4$ subunit significantly decreases the sensitivity of $\alpha 4 \beta 2$ channels to $A \beta_{1-42}$, which suggests that the relative block by $A \beta_{1-42}$ is affected by the stoichiometry of $\alpha 4 \beta 2$ channels $^{[12]}$. Numerous studies have revealed that $\mathrm{A} \beta_{1-42}$ regulates the function of non- $\alpha 7-\mathrm{nAChRs}$. However, links between losses in nAChRs, cholinergic neuronal degeneration and the effects of $A \beta$ have been elusive.

Histological studies showing co-expression of $\mathrm{nAChR}$ $\alpha 7$ and $\beta 2$ subunits in most forebrain cholinergic neurons ${ }^{[111]}$, and heterologous expression work indicating that $\mathrm{nAChR}$ $\alpha 7$ and $\beta 2$ subunits can come together to form heteromeric functional channels ${ }^{[112]}$, suggest that although most $\alpha 7$ nAChRs are formed as homomeric pentamers, others may exist as heteromers, including a possible $\alpha 7 \beta 2-\mathrm{nAChR}$ subtype. However, the expression of functional $\alpha 7 \beta 2$ - 
nAChRs in forebrain cholinergic neurons has not been demonstrated and their sensitivity to $A \beta$ has not been determined.

The predominant clinical syndrome associated with AD is a deficiency in both learning and memory capabilities. These deficits are thought to be due to selective forebrain cholinergic neuronal degeneration. Although this selective cholinergic neurodegeneration is largely unclear, several hypotheses have been postulated, including $A \beta$-induced toxicity, impairment of neuronal trophic support, disorders in glucose metabolism or other processes ${ }^{[113]}$. The accumu- lation and aggregation of the $\mathrm{A} \beta$ protein in diffuse neuritic plaques is a key pathological hallmark of $A D$. $A \beta$ accumulation is thought to contribute to cholinergic neuronal degeneration, in turn causing learning and memory deficits ${ }^{[114]}$. Evidence indicates that $\mathrm{A} \beta$ harms central neurons by affecting cellular $\mathrm{Ca}^{2+}$ homeostasis, neurotransmission, neuronal signaling and receptor/ion channel functions ${ }^{[115]}$. However, most of the relevant experiments have been done using $A \beta$ at concentrations ranging between $100 \mathrm{nmol} / \mathrm{L}$ and $10 \mu \mathrm{mol} / \mathrm{L}$, which are much higher than $\mathrm{A} \beta$ concentrations $(<5 \mathrm{nmol} / \mathrm{L})$

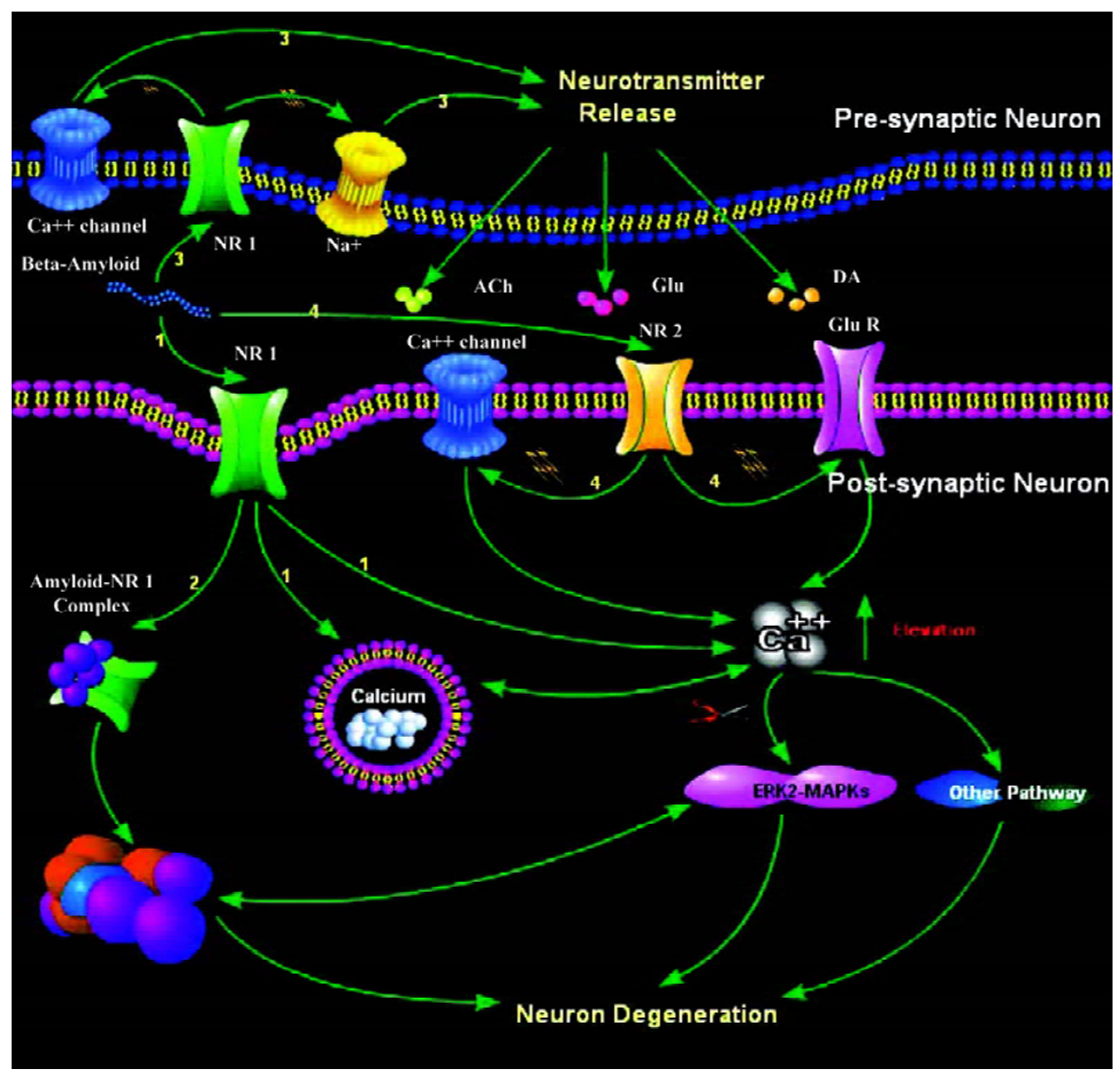

Figure 1. Roles of nAChRs in mediating A $\beta$ toxicity. NR1: $\alpha 7$-nAChRs; and NR2: non- $\alpha 7$-nAChRs; ER: endoplasmic reticulum ${ }^{[105-107]}$. Soluble $\mathrm{A} \beta_{1-42}$ accumulation: (1) activates $\alpha 7$-nAChRs and induces $\mathrm{Ca}^{2+}$ influx though this receptor and increases $\mathrm{Ca}^{2+}$ release from intracellular $\mathrm{Ca}^{2+}$ pools (ER), which together elevate intracellular $\mathrm{Ca}^{2+}$ concentrations; (2) intracellular $\alpha 7$-nAChRs combine with $\mathrm{A} \beta$ (co-localization) which favors intracellular plaque formation; (3) A $\beta$ activates pre-synaptic $\alpha 7$-nAChRs located on glutamatergic terminals and increases glutamate release, then activates ionotropic glutamate receptor and leads to $\mathrm{Ca}^{2+}$ influx via both the NMDA receptor and voltage-gated $\mathrm{Ca}^{2+}$ channels; and (4) A $\beta$ suppresses non- $\alpha 7$-nAChRs and causes receptor upregulation. These higher expressed non- $\alpha 7$-nAChRs (mostly $\alpha 4 \beta 2$-nAChRs) can be activated by endogenous $\mathrm{ACh}$ which leads to the depolarization of the membrane potential, and also leads to $\mathrm{Ca}^{2+}$ influx via both the NMDA receptor and voltage-gated $\mathrm{Ca}^{2+}$ channels. Together, $\mathrm{A} \beta$ acts on neuronal nAChRs and directly and/or indirectly elevates intracellular $\mathrm{Ca}^{2+}$ concentrations, which triggers neuronal degeneration through $\mathrm{Ca}^{2+}$-dependent signal cascades. 
found in the brain of patients with $\mathrm{AD}^{[116,117]}$. Moreover, the effects of $A \beta$ have been examined in a variety of cell types that may not be appropriate models to characterize the selective effects of $A \beta$ on native forebrain cholinergic neurons.

Figure 1 summarizes the roles of neuronal $n A C h R s$ in mediating $A \beta$-induced neuronal degeneration.

\section{Conclusion}

A marked reduction in the number of $n A C h R s$ is one of the major neurochemical features of AD in disease-relevant brain regions such as the cortex and hippocampus. This loss is accompanied by a deficiency in the number of forebrain cholinergic neurons, which contributes to the development of cognitive dysfunction. The precise mechanisms that underlie these losses are not yet fully defined. Further development of transgenic models recapitulating these important neurochemical characteristics may help to resolve these issues. Additional major challenges include understanding why aberrant $A \beta$ accumulation occurs, determining if accumulating $A \beta$ is indeed toxic and identifying the precise molecular mechanisms leading to synaptic dysfunction and neuronal degeneration. Such knowledge will help to identify and/or develop novel compounds that can restore cholinergic system function in patients with AD.

\section{Acknowledgement}

The authors thank Kevin ELLSWORTH for his assistance in preparing the manuscript.

\section{References}

1 Coyle JT, Price DL, DeLong MR. Alzheimer's disease: a disorder of cortical cholinergic innervation. Science 1983; 219: 118490 .

2 Aubert I, Araujo DM, Cecyre D, Robitaille Y, Gauthier S, Quirion $\mathrm{R}$. Comparative alterations of nicotinic and muscarinic binding sites in Alzheimer's and Parkinson's diseases. J Neurochem 1992; 58: 529-41.

3 Selkoe DJ. Alzheimer's disease results from the cerebral accumulation and cytotoxicity of amyloid $\beta$-protein. J Alzheimers Dis 2001; 3: 75-80.

4 Marin DB, Sewell MC, Schlechter A. Alzheimer's disease. Accurate and early diagnosis in the primary care setting. Geriatrics 2002; 57: 36-40; quiz 43.

5 Auld DS, Kornecook TJ, Bastianetto S, Quirion R. Alzheimer's disease and the basal forebrain cholinergic system: relations to $\beta$ amyloid peptides, cognition, and treatment strategies. Prog Neurobiol 2002; 68: 209-45.

6 Dolezal V, Kasparova J. $\beta$-amyloid and cholinergic neurons. Neurochem Res 2003; 28: 499-506.

7 Levin ED, Simon BB. Nicotinic acetylcholine involvement in cognitive function in animals. Psychopharmacology (Berl) 1998;
138: 217-30.

8 Newhouse PA, Kelton M. Clinical aspects of nicotinic agents: therapeutic applications in central nervous system disorders. In Clementi F, Gotti C, Fornasari D, editors. Handbook of experimental pharmacology: neuronal nicotinic receptors. Heidelberg: Springer; 1999. p 779-812.

9 Pettit DL, Shao Z, Yakel JL. $\beta$-Amyloid (1-42) peptide directly modulates nicotinic receptors in the rat hippocampal slice. $\mathrm{J}$ Neurosci 2001; 21: RC120.

10 Liu Q, Kawai H, Berg DK. $\beta$-Amyloid peptide blocks the response of $\alpha 7$-containing nicotinic receptors on hippocampal neurons. Proc Natl Acad Sci USA 2001; 98: 4734-9.

11 Dineley KT, Bell KA, Bui D, Sweatt JD. $\beta$-Amyloid peptide activates $\alpha 7$ nicotinic acetylcholine receptors expressed in Xenopus oocytes. J Biol Chem 2002; 277: 25056-61.

12 Lamb PW, Melton MA, Yakel JL. Inhibition of neuronal nicotinic acetylcholine receptor channels expressed in Xenopus oocytes by $\beta$-amyloid1-42 peptide. J Mol Neurosci 2005; 27: 13-21.

13 Pym L, Kemp M, Raymond-Delpech V, Buckingham S, Boyd CA, Sattelle D. Subtype-specific actions of $\beta$-amyloid peptides on recombinant human neuronal nicotinic acetylcholine receptors $(\alpha 7, \alpha 4 \alpha 2, \alpha 3 \alpha 4)$ expressed in Xenopus laevis oocytes. $\mathrm{Br}$ J Pharmacol 2005; 146: 964-71.

14 Hernandez CM, Terry AV Jr. Repeated nicotine exposure in rats: effects on memory function, cholinergic markers and nerve growth factor. Neuroscience 2005; 130: 997-1012.

15 Nordberg A, Hellstrom-Lindahl E, Lee M, Johnson M, Mousavi $\mathrm{M}$, Hall $\mathrm{R}$, et al. Chronic nicotine treatment reduces $\beta$-amyloidosis in the brain of a mouse model of Alzheimer's disease (APPsw). J Neurochem 2002; 81: 655-8.

16 White HK, Levin ED. Four-week nicotine skin patch treatment effects on cognitive performance in Alzheimer's disease. Psychopharmacology (Berl) 1999; 143: 158-65.

17 Seo J, Kim S, Kim H, Park CH, Jeong S, Lee J, et al. Effects of nicotine on APP secretion and $\mathrm{A} \beta$ - or CT(105)-induced toxicity. Biol Psychiatry 2001; 49: 240-7.

18 Lindstrom J, Anand R, Gerzanich V, Peng X, Wang F, Wells G. Structure and function of neuronal nicotinic acetylcholine receptors. Prog Brain Res 1996; 109: 125-37.

19 Albuquerque EX, Alkondon M, Pereira EF, Castro NG, Schrattenholz A, Barbosa CT, et al. Properties of neuronal nicotinic acetylcholine receptors: pharmacological characterization and modulation of synaptic function. J Pharmacol Exp Ther 1997; 280: 1117-36.

20 Lukas RJ, Changeux JP, Le Novère N, Albuquerque EX, Balfour DJK, Berg DK, et al. International Union of Pharmacology. current status of the nomenclature for nicotinic acetylcholine receptors and their subunits. Pharmacol Rev 1999; 51: 397-401.

21 Dajas-Bailador F, Wonnacott S. Nicotinic acetylcholine receptors and the regulation of neuronal signalling. Trends Pharmacol Sci 2004; 25: 317-24.

22 Clementi F, Fornasari D, Gotti C. Neuronal nicotinic receptors, important new players in brain function. Eur J Pharmacol 2000; 393: 3-10.

23 Jensen AA, Frolund B, Liljefors T, Krogsgaard-Larsen P. Neuronal nicotinic acetylcholine receptors: structural revelations, target identifications, and therapeutic inspirations. J Med Chem 2005; 48: 4705-45. 
24 Lukas RJ. Pharmacological effects of nicotine and nicotinic receptor subtype pharmacological profiles. In: George TP, editor. Medication treatments for nicotine dependence. Boca Raton: CRC Press; 2006. p 7-44.

25 Picciotto MR, Zoli M, Rimondini R, Lena C, Marubio LM, Pich $\mathrm{EM}$, et al. Acetylcholine receptors containing the $\alpha 2$ subunit are involved in the reinforcing properties of nicotine. Nature 1998; 391: 173-7.

26 Klink R, de Kerchove, d'Exaerde A, Zoli M, Changeux JP. Molecular and physiological diversity of nicotinic acetylcholine receptors in the midbrain dopaminergic nuclei. J Neurosci 2001; 21: 1452-63.

27 Champtiaux N, Changeux JP. Knockout and knockin mice to investigate the role of nicotinic receptors in the central nervous system. Prog Brain Res 2004; 145: 235-51.

28 Marubio LM, Gardier AM, Durier S, David D, Klink R, ArroyoJimenez MM, et al. Effects of nicotine in the dopaminergic system of mice lacking the $\alpha 4$ subunit of neuronal nicotinic acetylcholine receptors. Eur J Neurosci 2003; 17: 1329-37.

29 Tapper AR, McKinney SL, Nashmi R, Schwarz J, Deshpande P, Labarca $C$, et al. Nicotine activation of $\alpha 4 *$ receptors: sufficient for reward, tolerance, and sensitization. Science 2004; 306: 102932 .

30 Salminen O, Murphy KL, McIntosh JM, Drago J, Marks MJ, Collins AC, et al. Subunit composition and pharmacology of two classes of striatal presynaptic nicotinic acetylcholine receptors mediating dopamine release in mice. Mol Pharmacol 2004; 65: 1526-35.

31 McGehee DS, Role LW. Physiological diversity of nicotinic acetylcholine receptors expressed by vertebrate neurons. Annu Rev Physiol 1995; 57: 521-46.

32 Alkondon M, Pereira EF, Barbosa CT, Albuquerque EX. Neuronal nicotinic acetylcholine receptor activation modulates gammaaminobutyric acid release from CA1 neurons of rat hippocampal slices. J Pharmacol Exp Ther 1997; 283: 1396-411.

33 McGehee DS. Molecular diversity of neuronal nicotinic acetylcholine receptors. Ann N Y Acad Sci 1999; 868: 565-77.

34 Freeman JA. Possible regulatory function of acetylcholine receptor in maintenance of retinotectal synapses. Nature 1977; 269: $218-22$.

35 Chan J, Quik M. A role for the nicotinic $\alpha$-bungarotoxin receptor in neurite outgrowth in PC12 cells. Neuroscience 1993; 56: 44151.

36 Pugh PC, Berg DK. Neuronal acetylcholine receptors that bind $\alpha$-bungarotoxin mediate neurite retraction in a calcium-dependent manner. J Neurosci 1994; 14: 889-96.

37 Renshaw GM. [ $\left.{ }^{125} \mathrm{I}\right]$ - $\alpha$-bungarotoxin binding co-varies with motoneurone density during apoptosis. Neuroreport 1994; 5: 194952 .

38 Hory-Lee F, Frank E. The nicotinic blocking agents d-tubocurare and $\alpha$-bungarotoxin save motoneurons from naturally occurring death in the absence of neuromuscular blockade. J Neurosci 1995; 15: 6453-60.

39 Renshaw GM, Dyson SE. $\alpha$-BTX lowers neuronal metabolism during the arrest of motoneurone apoptosis. Neuroreport 1995; 6: $284-8$.

40 Treinin M, Chalfie M. A mutated acetylcholine receptor subunit causes neuronal degeneration in C elegans. Neuron 1995; 14 :
$871-7$.

41 Wonnacott S, Drasdo A, Sanderson E, Rowell P. Presynaptic nicotinic receptors and the modulation of transmitter release. Ciba Found Symp 1990; 152: 87-101; 102-5.

42 Alkondon M, Albuquerque EX. Diversity of nicotinic acetylcholine receptors in rat hippocampal neurons. I. Pharmacological and functional evidence for distinct structural subtypes. J Pharmacol Exp Ther 1993; 265: 1455-73.

43 Alkondon M, Pereira EF, Albuquerque EX. Mapping the location of functional nicotinic and gamma-aminobutyric acid A receptors on hippocampal neurons. J Pharmacol Exp Ther 1996; 279: 1491-506.

44 Dani JA, Radcliffe KA, Pidoplichko VI. Variations in desensitization of nicotinic acetylcholine receptors from hippocampus and midbrain dopamine areas. Eur J Pharmacol 2000; 393: 31-8.

45 Mike A, Castro NG, Albuquerque EX. Choline and acetylcholine have similar kinetic properties of activation and desensitization on the $\alpha 7$ nicotinic receptors in rat hippocampal neurons. Brain Res 2000; 882: 155-68.

46 Dani JA, De Biasi M. Cellular mechanisms of nicotine addiction. Pharmacol Biochem Behav 2001; 70: 439-46.

47 Champtiaux N, Gotti C, Cordero-Erausquin M, David DJ, Przybylski C, Lena C, et al. Subunit composition of functional nicotinic receptors in dopaminergic neurons investigated with knock-out mice. J Neurosci 2003; 23: 7820-9.

48 Wu P, Ma D, Pierzchala M, Wu J, Yang LC, Mai X, et al. The Drosophila acetylcholine receptor subunit D $\beta 5$ is part of an $\beta$ bungarotoxin binding acetylcholine receptor. J Biol Chem 2005; 280: 20987-94.

49 Wu M, Hajszan T, Leranth C, Alreja M. Nicotine recruits a local glutamatergic circuit to excite septohippocampal GABAergic neurons. Eur J Neurosci 2003; 18: 1155-68.

50 Thinschmidt JS, Frazier CJ, King MA, Meyer EM, Papke RL. Septal innervation regulates the function of $\alpha 7$ nicotinic receptors in CA1 hippocampal interneurons. Exp Neurol 2005; 195: $342-52$.

51 Thinschmidt JS, Frazier CJ, King MA, Meyer EM, Papke RL. Medial septal/diagonal band cells express multiple functional nicotinic receptor subtypes that are correlated with firing frequency. Neurosci Lett 2005; 389: 163-8.

$52 \mathrm{Fu} \mathrm{W,} \mathrm{Jhamandas} \mathrm{JH.} \alpha$-Amyloid peptide activates non- $\alpha 7$ nicotinic acetylcholine receptors in rat basal forebrain neurons. $J$ Neurophysiol 2003; 90: 3130-6.

53 Granon S, Poucet B, Thinus-Blanc C, Changeux JP, Vidal C. Nicotinic and muscarinic receptors in the rat prefrontal cortex: differential roles in working memory, response selection and effortful processing. Psychopharmacology 1995; 119: 139-44.

54 Levin ED. Nicotinic systems and cognitive function. Psychopharmacology 1992; 108: 417-31.

55 Sugaya K, Giacobini E, Chiappinelli VA. Nicotinic acetylcholine receptor subtypes in human frontal cortex: changes in Alzheimer's disease. J Neurosci Res 1990; 27: 349-59.

56 Rossner S, Ueberham U, Schliebs R, Perez-Polo JR, Bigl V. The regulation of amyloid precursor protein metabolism by cholinergic mechanisms and neurotrophin receptor signaling. Prog Neurobiol 1998; 56: 541-69.

57 Davies P, Maloney AJF. Selective loss of central cholinergic neurons in Alzheimer's disease. Lancet 1976; 2: 1403. 
58 Perry EK, Gibson PH, Blessed G, Perry RH, Tomlinson BE. Neurotransmitter enzyme abnormalities in senile dementia. Choline acetyltransferase and glutamic acid decarboxylase activities in necropsy brain tissue. J Neurol Sci 1977; 34: 247-65.

59 Court J, Martin-Ruiz C, Piggott M, Spurden D, Griffiths M, Perry E. Nicotinic receptor abnormalities in Alzheimer's disease. Biol Psychiatry 2001; 49: 175-84.

60 Nordberg A. Nicotinic receptor abnormalities of Alzheimer's disease: therapeutic implications. Biol Psychiatry 2001; 49: 20010 .

61 Nordberg A, Lundqvist H, Hartvig P, Andersson J, Johansson M, Hellstrom-Lindahi $\mathrm{E}$, et al. Imaging of nicotinic and muscarinic receptors in Alzheimer's disease: effect of tacrine treatment. Dement Geriatr Cogn Disord 1997; 8: 78-84.

62 Nordberg A, Lundqvist H, Hartvig P, Lilja A, Langstrom B. Kinetic analysis of regional $(\mathrm{S})(-)^{11} \mathrm{C}$-nicotine binding in normal and Alzheimer brains -- in vivo assessment using positron emission tomography. Alzheimer Dis Assoc Disord 1995; 9: 21-7.

63 Martin-Ruiz CM, Court JA, Molnar E, Lee M, Gotti C, Mamalaki $\mathrm{A}$, et al. A4 but not $\beta 3$ and $\beta 7$ nicotinic acetylcholine receptor subunits are lost from the temporal cortex in Alzheimer's disease. J Neurochem 1999; 73: 1635-40.

64 Aubert L, Araujo DM, Cecyre D, Robitaille Y, Gauthier S, Quirion R. Comparative alterations of nicotinic and muscarinic binding sites in Alzheimer's and Parkinson's diseases. J Neurochem 1992; 58: 529-41.

65 Hellstrom-Lindahl E, Mousavi M, Zhang X, Ravid R, Nordberg A. Regional distribution of nicotinic receptor subunit mRNAs in human brain: comparison between Alzheimer and normal brain. Brain Res Mol Brain Res 1999; 66: 94-103.

66 Mousavi M, Hellstrom-Lindahl E, Guan ZZ, Shan KR, Ravid R, Nordberg A. Protein and mRNA levels of nicotinic receptors in brain of tobacco using controls and patients with Alzheimer's disease. Neuroscience 2003; 122: 515-20.

67 Terzano S, Court JA, Fornasari D, Griffiths M, Spurden DP, Lloyd $\mathrm{S}$, et al. Expression of the $\alpha 3$ nicotinic receptor subunit mRNA in aging and Alzheimer's disease. Brain Res Mol Brain Res 1998; 63: $72-8$.

68 Burghaus L, Schutz U, Krempel U, de Vos RA, Jansen Steur EN, Wevers, A, et al. Quantitative assessment of nicotinic acetylcholine receptor proteins in the cerebral cortex of Alzheimer patients. Brain Res Mol Brain Res 2000; 76: 385-8.

69 Sparks DL, Beach TG, Lukas RJ. Immunohistochemical localization of nicotinic $\alpha 2$ and $\beta 4$ receptor subunits in normal human brain and individuals with Lewy body and Alzheimer's disease: preliminary observations. Neurosci Lett 1998; 256: 151-4.

70 Wevers A, Schroder H. Nicotinic acetylcholine receptors in Alzheimer's disease. J Alzheimers Dis 1999; 1: 207-19.

71 Zamani MR, Allen YS. Nicotine and its interaction with $\beta$-amyloid protein: a short review. Biol Psychiatry 2001; 49: 221-32.

72 Terry RD. The pathogenesis of Alzheimer disease: an alternative to the amyloid hypothesis. J Neuropathol Exp Neurol 1996; 55: 1023-5.

73 Terry RD, Masliah E, Salmon DP, Butters N, DeTeresa R, Hill R, et al. Physical basis of cognitive alterations in Alzheimer's disease: synapse loss is the major correlate of cognitive impairment. Ann Neurol 1991; 30: 572-80.

74 Klein WL. A $\beta$ toxicity in Alzheimer's disease: globular oligo- mers (ADDLs) as new vaccine and drug targets. Neurochem Int 2002; 41: 345-52.

75 McLean CA, Cherny RA, Fraser FW, Fuller SJ, Smith MJ, Beyreuther $\mathrm{K}$, et al. Soluble pool of $\mathrm{A} \beta$ amyloid as a determinant of severity of neurodegeneration in Alzheimer's disease. Ann Neurol 1999; 46: 860-6.

76 Lue LF, Kuo YM, Roher AE, Brachova L, Shen Y, Sue L, et al. Soluble amyloid $\beta$ peptide concentration as a predictor of synaptic change in Alzheimer's disease. Am J Path 1999; 155: 853-62.

77 Hsia AY, Masliah E, McConlogue L, Yu GQ, Tatsuno G, Hu K, et al. Plaque-independent disruption of neural circuits in Alzheimer's disease mouse models. Proc Natl Acad Sci USA 1999; 96: 322833 .

78 Westerman MA, Cooper-Blacketer D, Mariash A, Kotilinek L, Kawarabayashi T, Younkin LH, et al. The relationship between $\mathrm{A} \beta$ and memory in the Tg2576 mouse model of Alzheimer's disease. J Neurosci 2002; 22: 1858-67.

79 D'Andrea MR, Cole GM, Ard MD. The microglial phagocytic role with specific plaque types in the Alzheimer disease brain. Neurobiol Aging 2004; 25: 675-83.

80 McGeer PL, Klegeris A, Walker DG, Yasuhara O, McGeer EG. Pathological proteins in senile plaques. Tohoku J Exp Med 1994; 174: 269-77.

81 Anguiano M, Nowak RJ, Lansbury PT Jr. Protofibrillar islet amyloid polypeptide permeabilizes synthetic vesicles by a porelike mechanism that may be relevant to type II diabetes. Biochemistry 2002; 41: 11 338-43.

82 Janson J, Ashley RH, Harrison D, McIntyre S, Butler PC. The mechanism of islet amyloid polypeptide toxicity is membrane disruption by intermediate-sized toxic amyloid particles. Diabetes $1999 ; 48: 491-8$.

83 Mina EW, Demuro A, Kayed R, Milton S, Parker I, Glabe CG. Membrane disruption and elevated intracellular calcium as a common mechanism of amyloid oligomer-induced neurodegeneration. Neuroscience Abstracts 2004; 449: 20.

84 Bucciantini M, Calloni G, Chiti F, Formigli L, Nosi D, Dobson $\mathrm{CM}$, et al. Prefibrillar amyloid protein aggregates share common features of cytotoxicity. J Biol Chem 2004; 279: 31 374-82.

85 Colom LV, Diaz ME, Beers DR, Neely A, Xie WJ, Appel SH, et al. Role of potassium channels in amyloid-induced cell death. J Neurochem 1998; 70: 1925-34.

86 Pike CJ, Balazs R, Cotman CW. Attenuation of $\beta$-amyloid neurotoxicity in vitro by potassium-induced depolarization. J Neurochem 1996; 67: 1774-7.

87 Dougherty JJ, Wu J, Nichols RA. $\beta$-Amyloid regulation of presynaptic nicotinic receptors in rat hippocampus and neocortex. J Neurosci 2003; 30: 6740-7.

88 Grassi F, Palma E, Tonini R, Amici M, Ballivet M, Eusebi F. Amyloid $\alpha 1-42$ peptide alters the gating of human and mouse $\beta$ bungarotoxin-sensitive nicotinic receptors. J Physiol 2003; 547: 147-57.

89 Tozaki H, Matsumoto A, Kanno T, Nagai K, Nagata T, Yamamoto $\mathrm{S}$, et al. The inhibitory and facilitatory actions of amyloid- $\beta$ peptides on nicotinic ACh receptors and AMPA receptors. Biochem Biophys Res Commun 2002; 294: 42-5.

$90 \mathrm{Wu}$ J, Kuo YP, George AA, Xu L, Hu J, Lukas RJ. $\beta$-Amyloid directly inhibits human $\alpha 4 \beta 2$-nicotinic acetylcholine receptors heterologously expressed in human SH-EP1 cells. J Biol Chem 
2004; 279: 37 842-51.

91 Magdesian MH, Nery AA, Martins AH, Juliano MA, Juliano L, Ulrich $\mathrm{H}$, et al. Peptide blockers of the inhibition of neuronal nicotinic acetylcholine receptors by amyloid $\beta$. J Biol Chem 2005; 280: 31 085-90.

92 Avdulov NA, Chochina SV, Igbavboa U, O'Hare EO, Schroeder $\mathrm{F}$, Cleary JP, et al. Amyloid $\beta$-peptides increase annular and bulk fluidity and induce lipid peroxidation in brain synaptic plasma membranes. J Neurochem 1997; 68: 2086-91.

93 Muller WE, Koch S, Eckert A, Hartmann H, Scheuer K. $\beta$ Amyloid peptide decreases membrane fluidity. Brain Res 1995; 674: 133-6.

94 Kanfer JN, Sorrentino G, Sitar DS. Amyloid beta peptide membrane perturbation is the basis for its biological effects. Neurochem Res 1999; 24: 1621-30.

95 Arispe N, Pollard HB, Rojas E. The ability of amyloid $\beta$-protein [A $\beta \mathrm{P}(1-40)]$ to form $\mathrm{Ca}^{2+}$ channels provides a mechanism for neuronal death in Alzheimer's disease. Ann N Y Acad Sci 1994; 747: 256-66.

96 Sanderson KL, Butler L, Ingram VM. Aggregates of a $\beta$-amyloid peptide are required to induce calcium currents in neuron-like human teratocarcinoma cells: relation to Alzheimer's disease. Brain Res 1997; 744: 7-14.

97 Murray IV, Sindoni ME, Axelsen PH. Promotion of oxidative lipid membrane damage by amyloid $\beta$ proteins. Biochemistry 2005; 44: 12606-13.

98 Tabner BJ, El-Agnaf OM, Turnbull S, German MJ, Paleologou $\mathrm{KE}$, Hayashi $\mathrm{Y}$, et al. Hydrogen peroxide is generated during the very early stages of aggregation of the amyloid peptides implicated in Alzheimer disease and familial British dementia. J Biol Chem 2005; 280: 35 789-92.

99 Wang HY, Lee DH, D'Andrea MR, Peterson PA, Shank RP, Reitz AB. $\beta$-amyloid(1-42) binds to $\alpha 7$ nicotinic acetylcholine receptor with high affinity: Implications for Alzheimer's disease pathology. J Biol Chem 2000; 275: 5626-32.

100 Dineley KT, Westerman M, Bui D, Bell K, Ashe KH, Sweatt JD. $\beta$-amyloid activates the mitogen-activated protein kinase cascade via hippocampal $\alpha 7$ nicotinic acetylcholine receptors: In vitro and in vivo mechanisms related to Alzheimer's disease. J Neurosci 2001; 21: 4125-33.

101 Mills J, Laurent Charest D, Lam F, Beyreuther K, Ida N, Pelech $\mathrm{SL}$, et al. Regulation of amyloid precursor protein catabolism involves the mitogen-activated protein kinase signal transduction pathway. J Neurosci 1997; 17: 9415-22.

102 Nagele RG, D’Andrea MR, Anderson WJ, Wang HY. Intracellular accumulation of $\beta$-amyloid(1-42) in neurons is facilitated by the $\beta 7$ nicotinic acetylcholine receptor in Alzheimer's disease. Neuroscience 2002; 110: 199-211.
103 Michael R, D’Andrea, Daniel HSL, Wang HY, Nagele RG. Targeting intracellular A $\beta 42$ for Alzheimer's disease. drug discovery. Drug Dev Res 2002; 56: 194-200.

104 Alkondon M, Braga MF, Pereira EF, Maelicke A, Albuquerque EX. $\alpha 7$ nicotinic acetylcholine receptors and modulation of GABAergic synaptic transmission in the hippocampus. Eur J Pharmacol 2000; 393: 59-67.

105 Kihara T, Shimohama S, Urushitani M, Sawada H, Kimura J, Kume $\mathrm{T}$, et al. Stimulation of $\alpha 4 \beta 2$ nicotinic acetylcholine receptors inhibits $\beta$-amyloid toxicity. Brain Res 1998; 792: 331-4.

106 Burghaus L, Schutz U, Krempel U, de Vos RA, Jansen Steur EN, Wevers A, et al. Quantitative assessment of nicotinic acetylcholine receptor proteins in the cerebral cortex of Alzheimer patients. Brain Res Mol Brain Res 2000; 76: 385-8.

107 Levin ED, Rezvani AH. Nicotinic treatment for cognitive dysfunction. Curr Drug Targets CNS Neurol Disord 2002; 1 : 423-31.

108 Warpman U, Nordberg A. Epibatidine and ABT 418 reveal selective losses of $\alpha 4 \beta 2$ nicotinic receptors in Alzheimer brains. Neuroreport 1995; 6: 2419-23.

109 Rezvani AH, Levin ED. Cognitive effects of nicotine. Biol Psychiatry $2001 ; 49$ : 258-67.

110 Wang HY, Lee DH, Davis CB, Shank RP. Amyloid peptide A $\beta$ (1-42) binds selectively and with picomolar affinity to $\alpha 7$ nicotinic acetylcholine receptors. J Neurochem 2000; 75: 1155-61.

111 Azam L, Winzer-Serhan U, Leslie FM. Co-expression of $\alpha 7$ and $\beta 2$ nicotinic acetylcholine receptor subunit mRNAs within rat brain cholinergic neurons. Neuroscience 2003; 119: 965-77.

112 Khiroug SS, Harkness PC, Lamb PW, Sudweeks SN, Khiroug L, Millar NS, et al. Rat nicotinic ACh receptor $\alpha 7$ and $\beta 2$ subunits co-assemble to form functional heteromeric nicotinic receptor channels. J Physiol 2002; 540: 425-34.

113 Dolezal V, Kasparova J. $\beta$-amyloid and cholinergic neurons. Neurochem Res 2003; 28: 499-506.

114 Selkoe DJ. Translating cell biology into therapeutic advances in Alzheimer's disease. Nature 1999; 399: A23-31.

115 Fraser SP, Suh YH, Djamgoz MB. Ionic effects of the Alzheimer's disease $\beta$-amyloid precursor protein and its metabolic fragments. Trends Neurosci 1997; 20: 67-72.

116 Mehta PD, Pirttila T, Mehta SP, Sersen EA, Aisen PS, Wisniewski HM. Plasma and cerebrospinal fluid levels of amyloid $\beta$ proteins 1-40 and 1-42 in Alzheimer disease. Arch Neurol 2000; 57: 100-5.

117 Kuo YM, Kokjohn TA, Kalback W, Luehrs D, Galasko DR, Chevallier $\mathrm{N}$, et al. Amyloid- $\beta$ peptides interact with plasma proteins and erythrocytes: implications for their quantitation in plasma. Biochem Biophys Res Commun 2000; 268: 750-6. 